\title{
Analysis of Eductor Performance
}

by

J. L. Steimke

Westinghouse Savannah River Company

Savannah River Site

Aiken, South Carolina 29808

\section{MASTERY}

This paper was prepared in connection with work done under the above contract number with the U.S.

Department of Energy. By acceptance of this paper, the publisher and/or recipient acknowledges the U. S. Government's right to retain a nonexclusive, royalty-free license in and to any copyright covering this paper, along with the right to reproduce and to authorize others to reproduce all or part of the copyrighted paper. 


\section{DISCLAIMER}

This report was prepared as an account of work sponsored by an agency of the United States Government. Neither the United States Government nor any agency thereof, nor any of their employees, makes any warranty, express or implied, or assumes any legal liability or responsibility for the accuracy, completeness, or usefulness of any information, apparatus, product, or process disclosed, or represents that its use would not infringe privately owned rights. Reference herein to any specific commercial product, process, or service by trade name, trademark, manufacturer, or otherwise does not necessarily constitute or imply its endorsement, recommendation, or favoring by the United States Government or any agency thereof. The views and opinions of authors expressed herein do not necessarily state or reflect those of the United States Government or any agency thereof.

This report has been reproduced directly from the best available copy.

Available to DOE and DOE contractors from the Office of Scientific and Technical Information, P. O. Box 62, Oak Ridge, TN 37831; prices available from (423) 576-8401.

Available to the public from the National Technical Information Service, U. S. Department of Commerce, 5285 Port Royal Road, Springfield, VA 22161. 


\section{DISCLAIMER}

Portions of this document may be illegible in electronic image products. Images are produced from the best available original document. 
EES

ENGINEERED EQUIPMENT \& SYSTEMS

WSRC-TR-98-00208

KEYWORDS:

HB LINE

RETENTION:

PERMANENT

\section{ANALYSIS OF EDUCTOR PERFORMANCE (U)}

\section{Author:}

J. L. Steimke

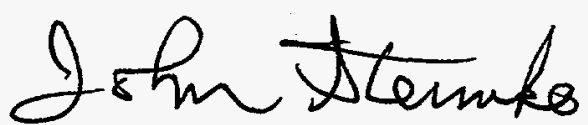

ISSUED: June 1998

SRTC SAVANNAH RIVER TECHNOLOGY CENTER, AIKEN, SC 29808

Westinghouse Savannah River Company

Prepared for the United States Department of Energy under Contract DE-AC09-96SR18500 
Document:

Title:
WSRC-TR-98-00208

Eductor Performance (U)

Approvals

M. R. Duignan, Technical Reviewer

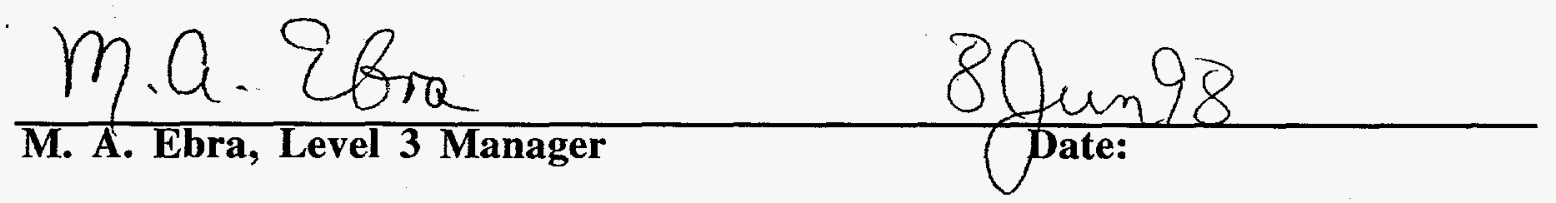





\section{CONTENTS}

1. INTRODUCTION

$1.1 \quad$ Background

1.2 Previous work

2. ANALYSIS 1

2.1 Description of Eductor and Associated Piping

2.2 Mathematical Model of Eductor

2.3 Mathematical Model of Associated Piping

2.4 Method of Solution

1

2

3

3. RESULTS OF MODEL

3.1 Parametric Results

3.2 Determination of Minimum Dilution Ratio

3.3 Uncertainty Analysis

4. CONCLUSIONS

5. ACKNOWLEDGMENTS

6. REFERENCES 8

7. TABLE 9

8. ATTACHMENT 10

9. FIGURES 11 

An eductor is used to both dilute and pump a plutonium bearing solution from either of the Product Hold Tanks (PHT) to Tank 11.1. The motive fluid, called eductant, is also the diluent. Dilution must be reliably controlled because of criticality concerns with Tank 11.1. The dilution ratio, the ratio of eductant flow to PHT flow, is controlled by installing a flow restrictor with an appropriate diameter between the PHT and the eductor. It had been expected that the dilution ratio would be a smoothly varying function of restrictor diameter. However, dilution ratios measured for liquid transfers showed unexpected trends. As a result, Engineered Equipment and Systems Department of SRTC was asked to analyze the eductor performance.

Eductor performance was modeled. The model accounted for tubing lengths and diameters, elevation changes, fittings, specific gravities and viscosities of liquids, vendor performance data for the eductor, corrosion inside the eductor and tubing, and dimensional changes caused by welding. The model agreed well with existing performance data and showed that the unexpected trends were the result of changes in the specific gravities of the PHT and the eductant. The model was used to make pre-test predictions of flows and dilution ratios for four transfers out of a PHT. Agreement between pre-test predictions and measured data was very good. Then the model was used to determine the eductant supply pressure that results in the lowest dilution ratio for any liquid specific gravities or eductant supply pressure. A restrictor diameter of $0.334 "$, an eductant specific gravity of 1.385 and a PHT specific gravity of 1.015 , an eductant supply pressure of 15 psig gave the lowest dilution ratio in the best estimate sense. Then an uncertainty analysis was performed which further reduced the minimum dilution ratio to 2.23 and gave a $99 \%$ confidence level.

It should be noted that the nozzle in the eductor is slowly corroding which will increase the dilution ratio for a given set of conditions. This is a conservative change. However, if the eductor were ever replaced the result would be a significant decrease in dilution ratio. It should also be noted that the PHT are, and are expected to continue to be, at room temperature. However, a change which increased the PHT temperature would decrease the dilution ratio. 


\section{INTRODUCTION}

\subsection{Background}

An eductor is used in HB Line to both dilute and pump a plutonium bearing solution from either of the Product Hold Tanks (PHT) to Tank 11.1. Dilution must be reliably controlled because of criticality concerns with Tank 11.1. The dilution ratio, the ratio of diluent (eductant) flow to PHT flow, has been controlled by installing a flow restrictor with an appropriate internal diameter between the PHT and the eductor. HB Line has used dilution ratios ranging from about 3 to 9 . It had been expected that the dilution ratio would be a smoothly varying function of restrictor diameter. However, dilution ratios measured for liquid transfers showed unexpected trends. As a result, Engineered Equipment and Systems Department of SRTC was asked to analyze the eductor performance.

\subsection{Previous work}

Lawson [1981] performed the experimental work that is the basis for the current design for the use of an eductor to pump and dilute a plutonium bearing solution. He tested the same Schutte and Koerting model 264, 1" eductor as is presently used at HB Line, but in a simpler flow loop where the motive fluid, or eductant, was water and the suction, or pumped fluid, was a solution of potassium carbonate with a specific gravity of 1.36 . The test variables were eductant pressure which ranged from 20 psig to 42 psig (mostly $30 \mathrm{psig}$ ) and suction lift which ranged from 33" to 110". Discharge pressures were close to atmospheric. The measured dilution ratio of the eductant flow to the suction flow for usable runs ranged from 3.9 to 5.2. Dilution ratio increased with increasing suction lift but was essentially independent of motive pressure.

\section{ANALYSIS}

\subsection{Description of Eductor and Associated Piping}

Figure 1 shows the present equipment layout in HB Line. One of the two PHT is selected by opening and closing the appropriate ball valves. A U shaped flow restrictor tube with the desired inside diameter is selected and installed in the line between the PHT and the eductor. A pump, not shown, pressurizes the eductant in a header, usually to $30 \mathrm{psig}$. This pressure is monitored by a gage located close to the header on the eductant line. The eductant line has an inside diameter of 0.652 " and contains 5 tubing bends with a radius to diameter ratio of 1.5. Eductant enters the top of the eductor, is accelerated to approximately 75 feet per second in the nozzle and then decelerates in the mixing chamber of the eductor, creating a pressure as low as -13 psig. This partial vacuum draws liquid out of the selected PHT, through the restrictor and into the suction side of the eductor. With the exception of the restrictor, the suction line has an inside diameter of $0.402^{\prime \prime}$ and contains eight tubing bends with a radius to diameter ratio of $1.5, \mathrm{a} 90^{\circ}$ elbow, two $90^{\circ}$ welded miter joints, one tee with flow through the run and one tee with flow through the branch.

The flow restrictor consists of three pieces welded together, a machined transition piece going from a diameter of 0.402 " to a smaller diameter, a piece of smaller tubing with two bends with a radius to diameter ratio of 2 and a machined transition piece going from the smaller diameter to $0.402 "$. The total included angle for the contraction and the expansion is $20^{\circ}$. Flow restrictor inside diameters range from 0.152 " to $0.402 "$ ". Chamfers were machined on all three pieces of metal comprising the flow restrictor prior to welding. According to S. L. West of SRTC the welding process is likely to cause metal to intrude into the flow passage by an amount equal to $25 \%$ of the tubing wall thickness. All of the tubing had a wall thickness of 0.049 " so the inside diameter at the weld was reduced by $0.025^{\prime \prime}$. Each intrusion was assumed to be hydraulically identical to an orifice plate.

Eductant and PHT fluid mix in the eductor, exit to the Foam Breaker and then flow to Tank 11.1. The Foam Breaker, Tank 11.1 and the PHT are connected to the vent system and are at the same, slightly sub-atmospheric pressure. Tank levels are monitored in both PHT and the eductant 
supply tank. Calibration curves are used to convert tank levels to volumes in liters. The slope of a plot of volume versus time gives flowrate.

There are two corrosion issues with the eductor and associated piping. The eductor was constructed from 316 stainless steel and everything else was constructed from 304L stainless steel. The first issue is that 316 stainless steel will slowly corrode in the nitric acid that flows through it. J. Greggi of NNMS estimated that corrosion could remove as much as 2 mil of metal per year or increase diameter by as much as 4 mils per year. The eductor has been used for about 9 years. The effect is most noticeable for the nozzle in the eductor which had a manufactured diameter of 0.197". The other corrosion issue is that the 304L stainless steel has been exposed to fluorides. Based on a discussion with Greggi the fluoride was estimated to have created a tubing roughness of 2 mils.

\subsection{Mathematical Model of Eductor}

The eductor manufacturer has published operating data for the Model 264, 1" eductor shown in Table 1. For those tests both the eductant and suction fluid were water. Eductant pressure, suction head and discharge pressure were varied and eductant and suction flows were measured. Eductant flow is limited by flow through a nozzle and should be proportional to the square root of the difference between eductant pressure and suction pressure. Figure 2 plots flow squared versus pressure loss across the nozzle. Note that this is different from the pressure gain generated by the eductor. With the exception of some points at high flows the data fall along a line. After setting aside data for flows greater than $10 \mathrm{gpm}$ the equation for the relationship follows where the pressure difference is in psid and the eductant flow is in gpm.

$$
\Delta \mathrm{P}_{\mathrm{noz}}=0.813 \mathrm{Fe}_{\mathrm{e}}^{2}
$$

The theoretical equation for the pressure drop through a nozzle follows.

$$
\Delta \mathrm{P}_{\mathrm{noz}}=\rho \mathrm{V}^{2} / 2 \mathrm{C}^{2}
$$

where $\mathrm{C}$ is the discharge coefficient for the nozzle. Using the manufacturing diameter of the nozzle, $5 \mathrm{~mm}$ or 0.197 " and equations 1 and 2, C was determined to be 0.96 , which is reasonable for a nozzle. As was mentioned before, corrosion could have increased the diameter of the nozzle by as much 0.004 " per year or to as large as $0.233 "$. Because pressure drop is inversely proportional to nozzle diameter to the fourth power, this dimensional change is expected to change the pressure drop equation to

$$
\Delta \mathrm{P}_{\text {noz }}=0.415 \mathrm{Fe}_{\mathrm{e}}^{2}
$$

However, the best fit to the existing flow data for the eductor and associated piping gave the following equation which was used in the model.

$$
\Delta \mathrm{P}_{\mathrm{noz}}=0.683 \mathrm{~F}_{\mathrm{e}}^{2}
$$

Equation 4 has a constant that is between the constants of equations 1 and 3 . This indicates some corrosion but not as much as the maximum amount.

Eductor pump curves for the Model 264, 1" eductor used with water (sp. gr. $=1.00$ ) are plotted in Figure 3 with eductant supply pressure as the parameter. Note that the pump curves for a particular eductant pressure fall nearly on a line. As suction flow increases, the pressure gain generated by the eductor decreases. For the purpose of modeling it was necessary to generate eductor pump curves for pressures other than those provided by the vendor. For eductant 
pressures between 20 and 30 psig the following method was used. A linear fit was passed through the data sets for eductant pressures of 20 and $30 \mathrm{psig}$. Linear interpolation was used to determine the operating curves for eductant pressures between 20 and 30 psig.

A different method was used to generate eductor pump curves for eductant pressures less than 20 psig. The data in Figure 3 were normalized to the basis of an eductant pressure of 10 psig by multiplying eductor pressure gain by the ratio of the basis pressure $(10 \mathrm{psig})$ to the actual eductant pressure. Suction flow was normalized by multiplying it by the square root of the ratio of the basis pressure to the actual eductant pressure. The reason for the square root functionality is that flow is usually proportional to the square root of pressure change. The common exception is for laminar flow which is not relevant here. The result of normalizing Figure 3 is shown in Figure 4. The scatter in the data were for normalized flows greater than 4.3 , however, those data could be ignored because actual normalized PHT flows are considerably less. A linear fit was passed through the data below 4.3 with the following result for normalized eductor pressure gain.

$$
\Delta \mathrm{P}_{\text {educ }} \frac{\mathrm{P}_{\text {basis }}}{\mathrm{P}_{\text {educ }}}=6.26-1.30 \mathrm{~F}_{\mathrm{PHT}} \sqrt{\frac{\mathrm{P}_{\text {basis }}}{\mathrm{P}_{\text {educ }}}}
$$

The data in Figures 3 and 4 were all for water. The eductor vendor recommended that the operating data could be extended to fluids with specific gravities different than water by multiplying flows by the inverse square root of specific gravity. No change is necessary for eductor pressure increases.

\subsection{Mathematical Model of Associated Piping}

Pressure drop for single phase flow in a pipe is described by equation 6 [Crane, 1988]

$$
\Delta P=\rho g \Delta h+\left(\frac{L f}{D}+\sum_{i=1}^{n} K_{i}\right) \frac{\rho V^{2}}{2}
$$

where $\rho, g, \Delta h, L, f, D, K_{i}, V$ are fluid density, acceleration of gravity, elevation change, pipe length, friction factor, inside diameter of the pipe, resistance coefficient for the $\mathrm{i}$-th component and fluid velocity, respectively. Friction factor is computed using the following equation [Aleman, et al., 1993]

$$
\mathrm{f}=\left[1.14-2 \log _{10}\left(\frac{\varepsilon}{\mathrm{D}}+\frac{21.25}{\operatorname{Re}^{0.9}}\right)\right]^{-2}
$$

where $\varepsilon$ and $\operatorname{Re}$ are the roughness of the pipe and Reynolds number, respectively. The equation is valid for turbulent Reynolds numbers up to $1,000,000$. The equation for Reynolds number is

$$
\operatorname{Re}=\frac{\mathrm{VD} \rho}{\mu}
$$

where $\mu$ is viscosity. The following resistance factors [Crane, 1988] were used for pipe components where $\theta$ is the total included angle for a gradual expansion or gradual contraction and $\beta$ is the ratio of the smaller diameter to the larger diameter for a contraction, expansion or orifice plate. The last resistance factor is from Blevins [1984]. 


\section{Table 2 Hydraulic Resistance Factors}

$\begin{array}{ll}\text { Component } & \mathrm{K} \\ \text { pipe inlet } & 0.78 \\ \text { standard } 90^{\circ} \text { elbow } & 30 \mathrm{f} \\ \text { standard tee, flow through run } & 20 \mathrm{f} \\ \text { standard tee, flow through branch } & 60 \mathrm{f} \\ \text { welded miter joint, } 90^{\circ} & 60 \mathrm{f} \\ \text { pipe bend } 90^{\circ}, \mathrm{r} / \mathrm{D}=1.5 & 14 \mathrm{f} \\ \text { pipe bend } 90^{\circ}, \mathrm{r} / \mathrm{D}=2 & 12 \mathrm{f} \\ \text { gradual contraction, } \theta<45^{\circ} & \mathrm{K}_{\mathrm{c}}=0.8(\sin \theta / 2)\left(1-\beta^{2}\right) \\ \text { gradual expansion, } \theta<45^{\circ} & \mathrm{K}_{\mathrm{e}}=2.6(\sin \theta / 2)\left(1-\beta^{2}\right)^{2} \\ & \mathrm{~K}_{\mathrm{o}}=\frac{\zeta}{\mathrm{C}^{2}} \frac{1}{\beta^{2}}\left[1-\beta^{4}\right] \\ \text { orifice plate } & \end{array}$

Blevins gives tabular data for the orifice discharge coefficient, $\mathrm{C}$, and the dimensionless coefficient, $\zeta$. The typical value of 0.60 was used for $\mathrm{C}$ and the Blevins table was curve fit to obtain $\zeta$ for use in the model. For some $\mathrm{H}$ Canyon transfers with the eductor before March 1998 the molarity of the eductant or PHT solution was recorded but not the specific gravity. Therefore, the capability was needed to convert molarity to specific gravity. Data for the specific gravities, $\mathrm{S}$, of solutions of nitric acid with a range of molarities were found in Perry, et, al., [1963] and fit with the following polynomial curve fit.

$$
\mathrm{S}=0.999+0.03364 \mathrm{M}-0.0001535 \mathrm{M}^{2}-0.00001988 \mathrm{M}^{3}
$$

The viscosities of the eductant and PHT are not measured. For the purpose of estimating viscosity the fluid was assumed to be an aqueous solution of nitric acid. Data for viscosities of solutions of nitric acid with a range of specific gravities were found in Perry, et, al. [1963] and fit with the following polynomial curve fit where $\mu_{\mathrm{w}}$ is the viscosity of water.

$$
\mu / \mu_{\mathrm{w}}=0.0256+7.805 \mathrm{~S}-13.14 \mathrm{~S}^{2}+6.313 \mathrm{~S}^{3}
$$

The eductant and the PHT fluid are always close to $70^{\circ} \mathrm{F}$. Kreith [1973] states the viscosity of water at $70^{\circ} \mathrm{F}$ to be $0.000658 \mathrm{lb} / \mathrm{ft} \mathrm{sec}$.

The fluid in the PHT was assumed to saturated with air. For the purpose of the gas solubility calculation the fluid was assumed to be water. Henry's Law states that absolute pressure of a solution of gas in a liquid divided by mole fraction of dissolved gas is equal to a constant. The Henry's Law constant for air in water [Perry, et, al., 1963] is $6.64 \times 10^{4} \mathrm{~atm}$ at $20^{\circ} \mathrm{C}\left(68^{\circ} \mathrm{F}\right)$. Therefore, at one atmosphere the mole fraction of dissolved air is $1.51 \times 10^{-5}$. One liter of water has a mass of $1 \mathrm{~kg}$ or 55.6 moles. Therefore, at saturation that liter contains $8.4 \times 10^{-5}$ moles of air or $2 \%$ air by volume at ambient conditions. Decreasing the pressure brings this air out of solution and also increases its volume in accordance with the Ideal Gas Law

$$
\alpha=\frac{0.02 \mathrm{P}_{\mathrm{v}}}{\mathrm{P}_{\mathrm{v}}-\Delta \mathrm{P}_{\text {suc }}-\mathrm{P}_{\text {sat }}}
$$

where $P_{v}$ is the pressure in the ventilation system, estimated to be $14.55 \mathrm{psia}, \Delta \mathrm{P}_{\text {suc }}$ is the pressure drop from the PHT to the suction of the eductor and $\mathrm{P}_{\text {sat }}$ is the vapor pressure of water, 
$17 \mathrm{~mm} \mathrm{Hg}$ or 0.33 psia at $20^{\circ} \mathrm{C}$. The denominator of equation 11 is the partial pressure of air at the suction of the eductor. The pressure in the suction line decreases from near atmospheric in the PHT to the lowest value at the suction to the eductor. Therefore, the void fraction increases in the direction of flow. The effective void fraction in the suction line was approximated as half of the maximum void fraction calculated to occur at the location of the eductor suction using equation 11 .

Adding gas to a liquid flow creates a two phase mixture and changes the calculation of pressure drop in equation 6 because the frictional pressure drop increases and the head term decreases. There are various methods to calculate the two phase effect. The homogeneous model [Wallis, $1969]$ is simple and fairly accurate for void fractions less than $25 \%$. In this model the frictional terms are divided by the term $(1-\alpha)$ and the head terms are multiplied by $(1-\alpha)$. The result of converting equation 6 to two phase flow follows.

$$
\Delta \mathrm{P}_{\mathrm{tp}}=\rho \mathrm{g} \Delta \mathrm{h}(1-\alpha)+\left(\frac{\mathrm{Lf}}{\mathrm{D}}+\sum_{\mathrm{i}=1}^{\mathrm{n}} \mathrm{K}_{\mathrm{i}}\right) \frac{\rho \mathrm{V}^{2}}{2(1-\alpha)}
$$

\subsection{Method of Solution}

The equation set was entered into a Trapeze ${ }^{\circledR}$ spreadsheet listed in Attachment 1. Tubing lengths, diameters and specific gravities were entered. Trial values of the eductant flow and PHT flow were input. Two loop pressures were computed, the first for the suction line, the second for the eductant line. Going from the air space in the top of the PHT, there is a pressure gain due to hydrostatic head moving down to the inlet of the suction tube inside the tank, a pressure loss moving along the suction line, a pressure gain generated by the eductor and a net pressure gain moving downward along the discharge tube. The total pressure change for the terms described above should be zero. Going from the supply of eductant there is a pressure increase generated by a pump, a pressure decrease moving along the eductant line, a pressure decrease in the nozzle of the eductor and a net pressure gain moving downward along the discharge tube. Once again the total pressure change for the terms described above should be zero. Manual iteration was used on the two flows until both loop pressure drops were equal to zero.

\section{RESULTS OF MODEL}

\subsection{Parametric Results}

Figure 5 plots the computed dilution ratio as a function of restrictor diameter with specific gravity in the PHT as a parameter. In all cases the specific gravity of the eductant is 1.065 or 2 molar nitric acid and the eductant header is at 30 psig. For restrictor diameters less than 0.24 ", the dilution ratio is a strong function of restrictor diameter. For restrictor diameters greater than 0.32 ", the dilution ratio is a weak function of restrictor diameter. Increasing the PHT specific gravity increases the dilution ratio. The reason is that it is harder to pump the PHT fluid because it is denser and more viscous.

Figures 6 through 8 replot the dilution ratios of Figure 5 and compare the model with transfer data collected prior to March 1998. Figures 6, 7 and 8 are for PHT specific gravities of 1.13, 1.248 and 1.385 , respectively. The pressure in the eductant header was always $30 \mathrm{psig}$. There is good agreement between calculated and measured dilution ratios.

The model was used to make pre-test predictions of flows during transfers made at HB Line on April 23, June 1 and June 2, 1998. Table 3 compares predictions of flows and dilution ratios (the first line of a pair) to the actual values measured later (the second line of the pair). 
Table 3 Validation of Model With Pre-Test Predictions.

\begin{tabular}{|c|c|c|c|c|c|c|c|}
\hline $\begin{array}{l}\text { Date of } \\
\text { transfer }\end{array}$ & $\begin{array}{l}\text { restrictor } \\
\text { i. d., } \\
\text { inch }\end{array}$ & $\begin{array}{l}\text { PHT } \\
\text { sp gr }\end{array}$ & $\begin{array}{l}\text { eductant } \\
\text { sp gr }\end{array}$ & $\begin{array}{l}\text { eductant } \\
\text { pres., } \\
\text { psig }\end{array}$ & $\begin{array}{l}\text { eductant } \\
\text { flow, } \\
\text { gpm }\end{array}$ & $\begin{array}{l}\text { PHT } \\
\text { flow, } \\
\text { gpm }\end{array}$ & ratio \\
\hline prediction & 0.152 & 1.254 & 1.07 & 20 & 6.2 & 0.74 & 8.38 \\
\hline $4 / 23 / 98$ & 0.152 & 1.254 & 1.07 & 20 & 6.1 & 0.80 & 7.63 \\
\hline prediction & 0.334 & 1.015 & 1.385 & 20 & 5.31 & 2.00 & 2.66 \\
\hline $6 / 1 / 98$ & 0.334 & 1.015 & 1.385 & 20 & 5.61 & 2.24 & 2.50 \\
\hline prediction & 0.152 & 1.015 & 1.385 & 30 & 6.56 & 1.05 & 6.24 \\
\hline $6 / 2 / 98$ & 0.152 & 1.015 & 1.385 & 30 & 6.54 & 0.96 & 6.81 \\
\hline prediction & 0.152 & 1.015 & 1.385 & 20 & 5.47 & 0.91 & 6.0 \\
\hline $6 / 2 / 98$ & 0.152 & 1.015 & 1.385 & 20 & 5.45 & 0.90 & 6.06 \\
\hline
\end{tabular}

The best agreement was for the fourth transfer. For all four transfers the predicted and measured eductant flows agreed to within $\pm 6 \%$. The predicted and measured PHT flows agreed to within $\pm 8 \%$. The flow ratios agreed to within $\pm 10 \%$. Overall, the agreement is very good considering all of the factors that had to be accounted for and the fact that the eductant pressure measurement is probably accurate to no better than \pm 1 psi.

\subsection{Determination of Minimum Dilution Ratio}

HB Line Engineering requested a calculation of the minimum dilution ratio for any PHT specific gravity, any eductant specific gravity, any tank fullness, any eductant pressure and a restrictor diameter of $0.334 "$. Increasing the tank fullness decreases the distance that it is necessary to lift the liquid and therefore increases the PHT flow and decreases the dilution ratio. Therefore, the tank fullness was set to $100 \%$. Decreasing the PHT specific gravity decreases its density and viscosity making it easier to pump and decreases the dilution ratio. Therefore, the PHT specific gravity was set at the minimum value of 1.016. Increasing the eductant specific gravity increases its density and viscosity making it harder to pump and decreases the dilution ratio. Therefore, the eductant specific gravity was set at the maximum value of 1.385 . Figure 9 shows the result of varying the pressure in the eductant header for the above conditions. The minimum dilution ratio is 2.52 for an eductant pressure of 15 psig. As the eductant pressure is increased above 15 psig the dilution ratio slowly increases. One reason for this is that higher eductant pressures create higher void fractions in the suction line which reduce the flow from the PHT. As the eductant pressure is decreased below 15 psig the dilution ratio also increases, slowly at first, then faster. The reason is that the pressure generated by the eductor starts to become only marginally larger than the head required to lift the fluid out of the PHT.

\subsection{Uncertainty Analysis}

The root sum square method was used for the uncertainty analysis. The method is to first compute the dilution ratio for the nominal worst case conditions which are a full PHT, an eductant specific gravity of 1.385 , a PHT specific gravity of 1.015 , and an eductant pressure of $15 \mathrm{psig}$. The analysis also used a restrictor diameter of 0.334 inch. That dilution ratio is 2.52 . The $99 \%$ confident uncertainties of various parts of the calculation were estimated. The uncertainty was added to or subtracted from the part of the calculation under consideration. The calculation of dilution ratio was repeated to determine the effect of that particular uncertainty. 


\section{Table 4 Factors in Uncertainty Analysis}

Part of calculation

1. diameter of suction line

2. diameter of restrictor

3. diameter of eductant line

4. length of suction line

5. number of velocity head losses in suction line

6. fraction factor for suction line

7. pressure gain for eductor

8. pressure.loss for nozzle
Change

$+0.005^{\prime \prime}$

$+0.005^{\prime \prime}$

$-0.005^{\prime \prime}$

$-0.5^{\prime}$

$-2$

$-10 \%$

$+30 \%$

$+15 \%$
Dilution ratio

2.46

2.51

2.52

2.51

2.46

2.42

2.33

2.35
Change in ratio

0.06

0.01

0

0.01

0.06

0.10

0.19

0.17

For the eight parts of the calculation listed above, the root sum square change in dilution ratio is 0.29 . Subtracting 0.29 from 2.52 gives the minimum flow ratio of 2.23 .

\section{CONCLUSIONS}

a. The minimum dilution ratio was computed for a full PHT, an eductant specific gravity of 1.385 , a PHT specific gravity of 1.015 , an eductant pressure of $15 \mathrm{psig}$ and a restrictor diameter of 0.334 inch. An uncertainty analysis concluded that the $99 \%$ confident minimum dilution ratio is 2.23 .

b. The unexpected trends in dilution ratio were largely the result of changes in the specific gravities of the PHT and the eductant.

c. Because of corrosion of the eductor, the dilution ratio will continue to slowly increase at a rate of about $1 \%$ per year. If the eductor were replaced with the same model, the dilution ratio would decrease about $8 \%$.

d. The use of eductant at $30 \mathrm{psig}$ can create pressures in the suction line as low as $-13 \mathrm{psig}$, which will result in void formation and possible foaming. The formation of void can be reduced by decreasing the eductant pressure to 20 psig. The reduction of flowrate is only $17 \%$ which has a modest impact on the time required to complete a transfer.

e. Increasing the size of the flow restrictor decreases the dilution ratio, however, the effect is small for restrictor diameters greater than $0.32 "$.

f. Increasing the eductant specific gravity decreases the dilution ratio.

g. Increasing the eductant temperature decreases its viscosity and increases the dilution ratio.

h. Increasing the PHT specific gravity increases the dilution ratio.

i. At present, there is no credible mechanism for heating the contents of the PHT above room temperature. However, if the PHT temperature did increase this would decrease its viscosity and decrease the dilution ratio.

\section{ACKNOWLEDGMENTS}

Bruce Tomlin and Doug Melton provided invaluable information on the eductor system. 
WSRC-TR-98-00208

page 8

6. REFERENCES

S. E. Aleman, G. P. Flack, L. L. Hamm, S. Y. Lee and F. G. Smith, "Flowtran TF Software Design", WSRC-TR-92-532, February 1993.

Robert D. Blevins, Applied Fluid Dynamics Handbook, 1984.

Crane Co., Flow of Fluids Through Valves, Fittings and Pipe, 1988.

Frank Keith, Principles of Heat Transfer, 1973.

J. R. Lawson, "Eductor Testing for Waste Dilution", Dec. 28, 1981.

Robert H. Perry, Cecil H. Chilon, Sidney D. Kirkpatrick, Chemical Engineers' Handbook, Fourth Edition, 1963.

G. B. Wallis, One-dimensional Two-phase Flow, 1969. 
$6 / 6 / 98$ at $10: 30$

molarity suc

molarity educ

gpm suc

gpm educ

tank fullness

suction diameter, inch

restrictor diameter, inch

educ diameter, inch

suction length, $\mathrm{ft}$

restrictor length, $\mathrm{ft}$

eductant length, $\mathrm{ft}$

suction sp gr

eductant $\mathrm{sp} \mathrm{gr}$

discharge $\mathrm{sp} g r$

viscosity suc, lb/ft sec

viscosity educ, $\mathrm{lb} / \mathrm{ft} \mathrm{sec}$

vel suc, $\mathrm{ft} / \mathrm{sec}$

vel res, $\mathrm{ft} / \mathrm{sec}$

vel dis, $\mathrm{ft} / \mathrm{sec}$

vel educ, $\mathrm{ft} / \mathrm{sec}$

n suc

$n$ dis

n educ

$n$ res

Re suction

Re restrictor

Re educ

$f$ suction

$f$ restrìctor

f educ

$K$ non recoverable

$K$ weld

DP fric suc,psid

DP fric res,psid

$P$ educ, psig

DP suc, psid

DP dis, psid

average void fraction

dilution ratio

DP educ, psid

DP noz, psid

noz DP error, psid

suc DP error, psid

DP educ all

DP educ 1020 , psid

DP educ 20 30, psid

DP educ 020 , psid
14

0.5

1.847

4.643

1

0.402

0.339

0.652

19

0.725

3.92

1.015

1.385

1.280

0.00066

0.00158

4.67

6.57

3.27

4.46

20.49

13.13

0.51

2.53

0.648

14937

17713

13297

0.0361

0.0270

$\begin{array}{ll}0.693 & 0.0288\end{array}$

0.078

0.261

5.01

0.49

14.15

6.14

$-0.25$

0.018

2.51

6.00

20.40

$-0.003$

0.003

6.00

5.90

6.31

6.00 (sp gr suc*gpm suc+sp gr educ*gpm educ)/(gpm suc+gpm educ) poly(sp gr suc,fit vis) ${ }^{\star} 0.000658$

poly(sp gr educ,fit vis) ${ }^{\star} 0.000658$

gpm suc ${ }^{\star} 0.1337 / 60 /\left(\# P I^{*} D\right.$ suc^2/4/144)

gpm suc*0.1337/60/(\#PI*D res^2/4/144)

(gpm suc+gpm educ)*0.1337/60/(\#PI*0.9^2/4/144)

gpm educ ${ }^{*} 0.1337 / 60 /\left(\right.$ \#I $^{*} D$ educ $\left.{ }^{\wedge} 2 / 4 / 144\right)$

$0.78+\left(3^{*} 60+20+30+8^{*} 14\right)^{*} \mathrm{f}$ suc

$14^{*} \mathrm{f}$ suc

$5^{\star} 14^{\star *} \mathrm{f}$ suc

$2^{*} 12^{*} \mathrm{f}$ res

D suc/12*62.4*sp gr suc*vel suc/vis suc

D res $/ 12^{*} 62.4^{*} \mathrm{sp}$ gr suc*vel res/vis suc

$\mathrm{D}$ educ $/ 12^{\star} 62.4^{*} \mathrm{sp} \mathrm{gr}$ educ $^{*} \mathrm{vel}$ educ/vis educ

$1 /\left(1.14-2^{*} \log 10(\text { rough/D suc+21.25/Re suc^0.9) })^{\wedge} 2\right.$

$1 /\left(1.14-2^{*} \log 10\left(\text { rough new/D res+21.25/Re } \operatorname{res}^{\wedge} 0.9\right)\right)^{\wedge} 2$

$1 /\left(1.14-2^{*} \log 10(\text { rough new/D educ+21.25/Re educ^0.9) })^{\wedge} 2\right.$

$\left(0.8^{\star} 0.1736^{\star}\left(1-D\right.\right.$ res^2/D suc $\left.^{\wedge} 2\right)+2.6^{*} 0.1736^{*}(1-D$ res^ $2 / D$ si $2^{\star} a^{*}(D \text { res } /(D \text { res }-0.025))^{\wedge} 2^{*}\left(1-((D \text { res }-0.025) / D \text { res })^{\wedge} 4\right) / 0 . \epsilon$ (f suc ${ }^{\star} \mathrm{L}$ suc/(D suc/12)+n suc) ${ }^{\star} \mathrm{sp}$ gr suc ${ }^{\star} 62.4 / 32.2^{\star} \mathrm{vel}$ suc^${ }^{\wedge} 2 / 6$ (f res ${ }^{*} \mathrm{~L}$ res/(D res/12) $+\mathrm{Knr}+\mathrm{K}$ weld $+n$ res) ${ }^{\star}$ vel res^ $2^{\star} \mathrm{sp}$ gr si $P$ supply-(f educ* $L$ educ/(D educ/12) $+n$ educ) ${ }^{*}$ sp gr educ*62.4/3؛ $\left(60.5-12-31^{*}\right.$ full) $/ 12^{*} \mathrm{sp}$ gr suc ${ }^{*} 62.4 / 144+(\mathrm{DP}$ fric suc+DP fric $-6.5 / 12^{*}$ sp gr dis*62.4/144+n dis*sp gr dis*62.4/32.2*vel dis^ $0.02 / 2 * 14.55 /(14.55-D P$ suc-Psat $)$

gpm educ/gpm suc

if( $P$ educ $>20, D P$ educ 20 30,DP educ 0 20)

$0.813 / 1.19^{*} \mathrm{sp}$ gr educ ${ }^{\star} \mathrm{gpm}$ educ $^{\wedge} 2$

$-P$ educ+DP noz-DP suc/(1-void)

-DP educ+DP suc/(1-void)+DP dis

poly(gpm suc/(P educ/10)^0.5, fit all $)^{\star}(P$ educ/10)

$\left(P\right.$ educ-10)/10*poly $\left(g p m \cdot\right.$ suc $^{\star}$ sp gr educ^exp,fit educ 20$)+(1-(P \leftarrow$

$(P$ educ-20)/10*poly(gpm suc*sp gr educ^exp,fit educ 30$)+(1-(P$ \& if( $P$ educ $>15, D P$ educ 10 20,DP educ all) 
page 10

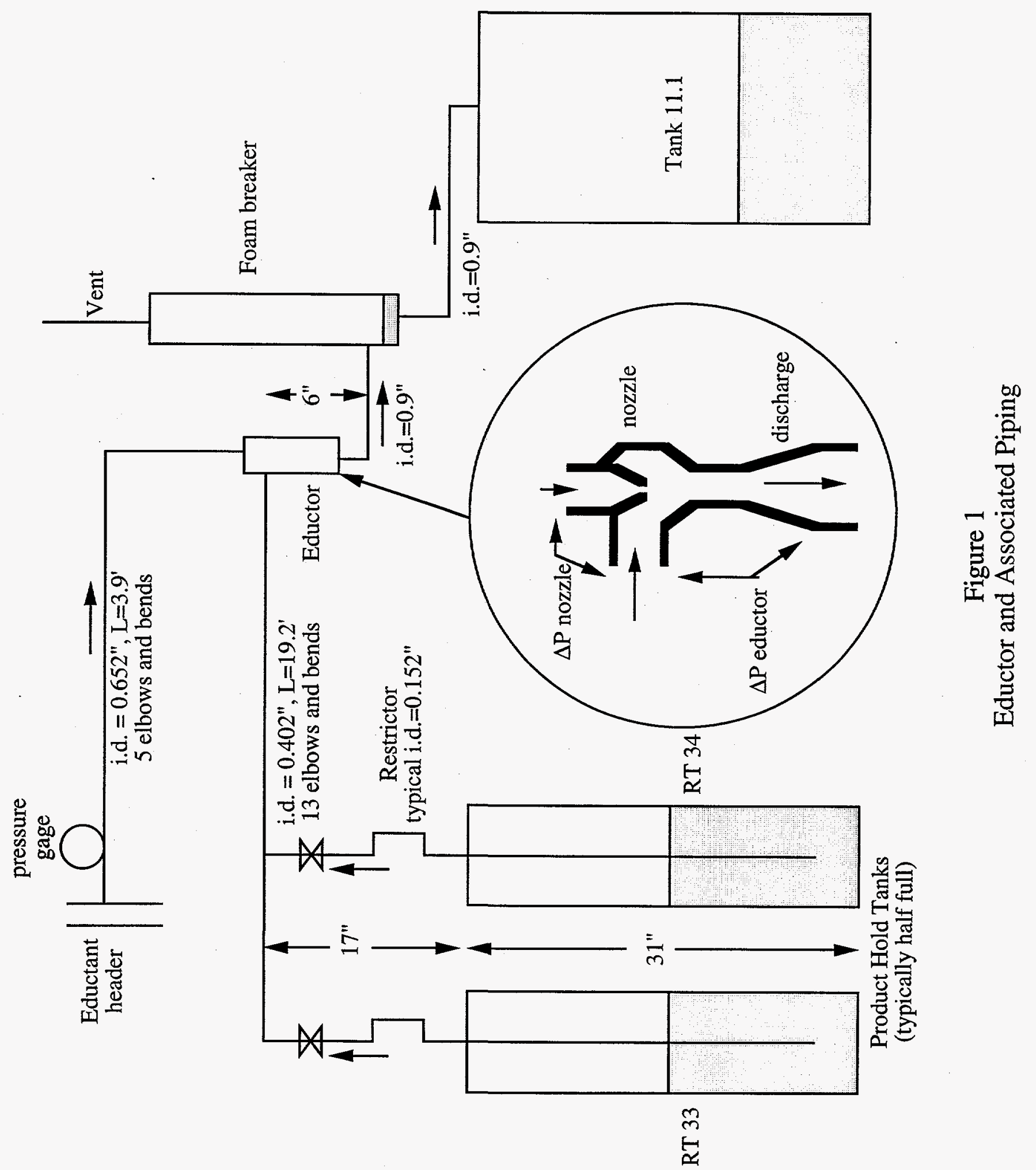




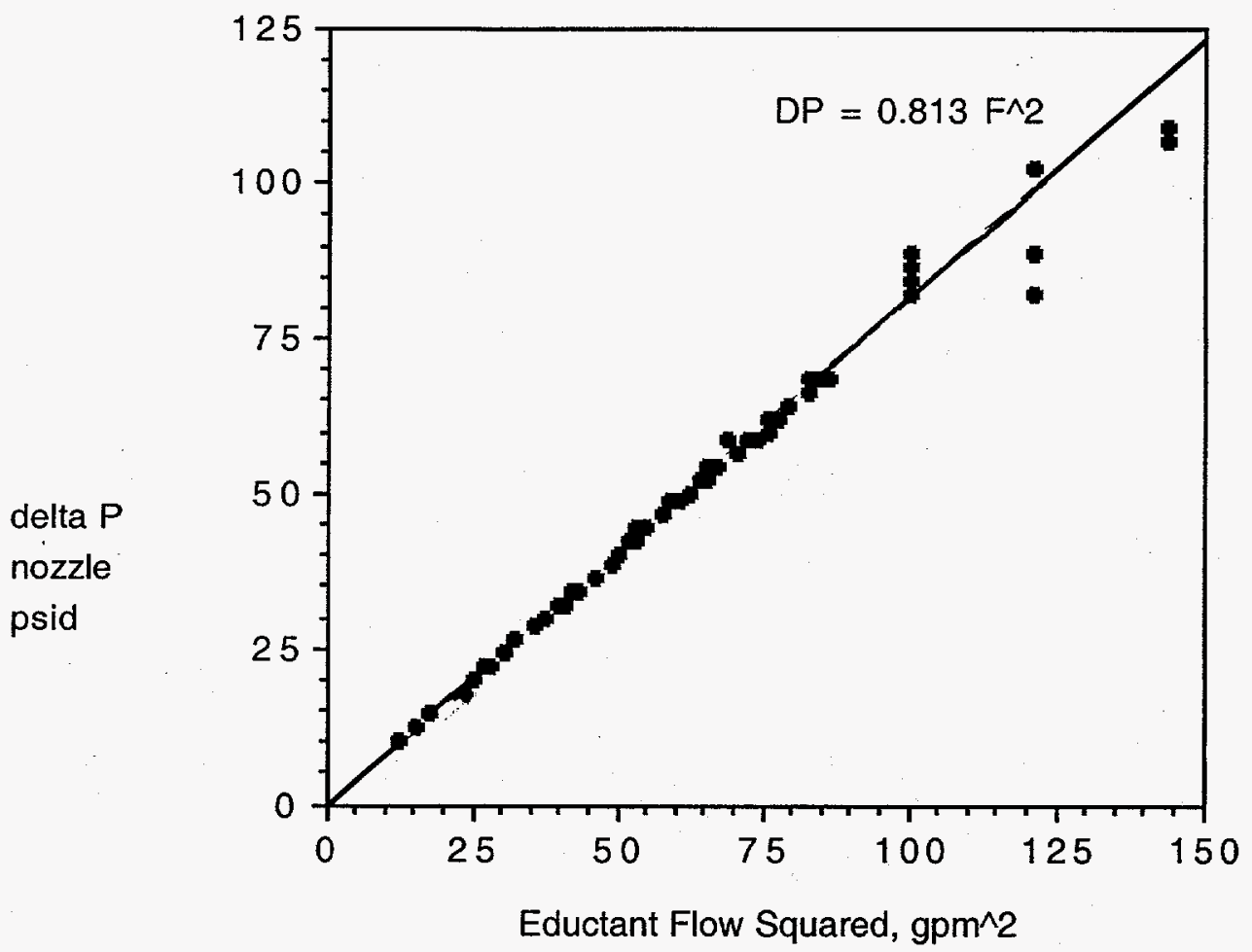

Figure $2 \quad$ Pressure Drop Across Nozzle of 1" Eductor for Water

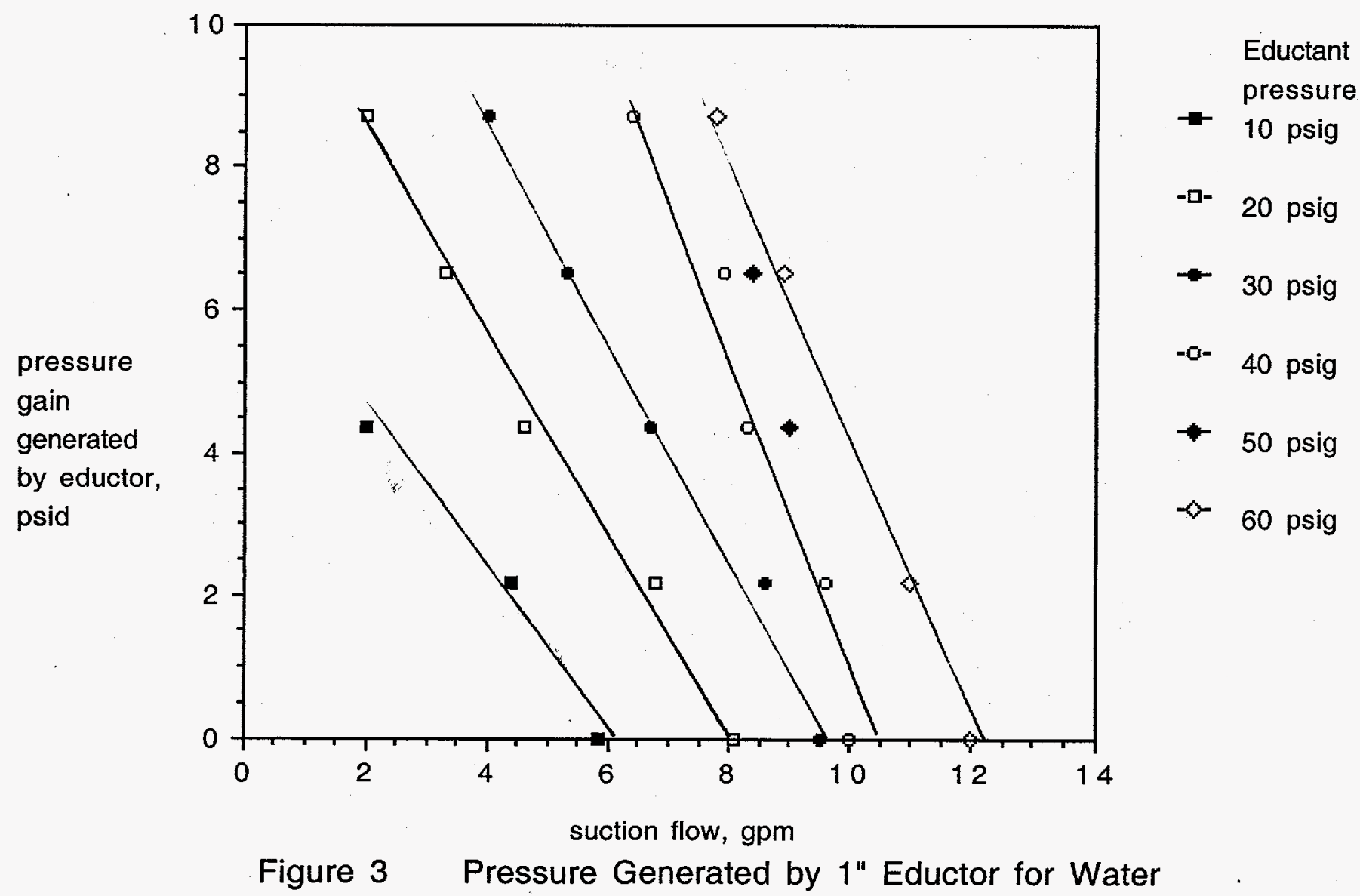


$6 / 8 / 98$ at $11: 52 \quad$ page 12

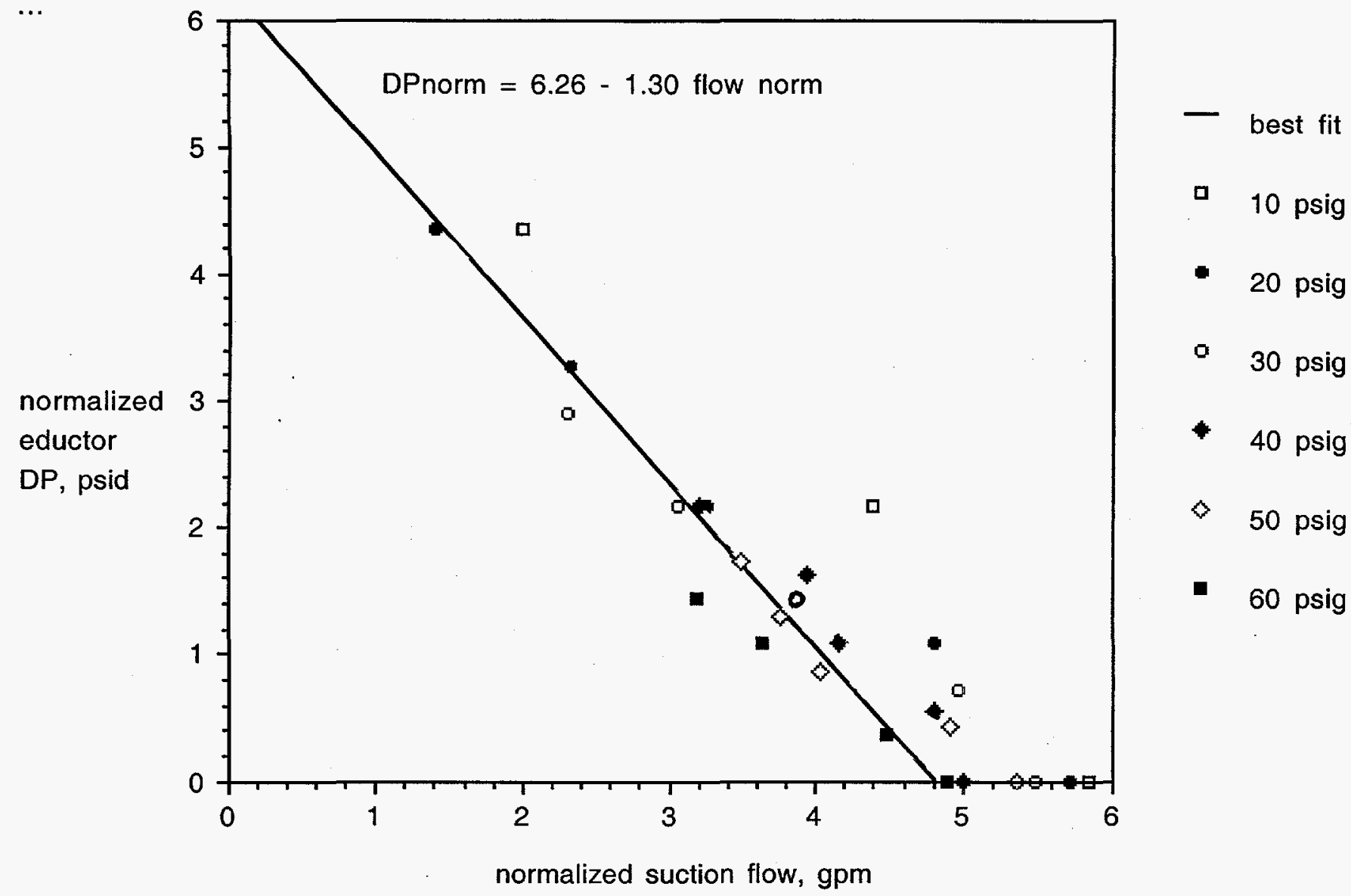

Figure 4 Normalized Pressure Generated by Eductor 


$$
\text { page } 13
$$

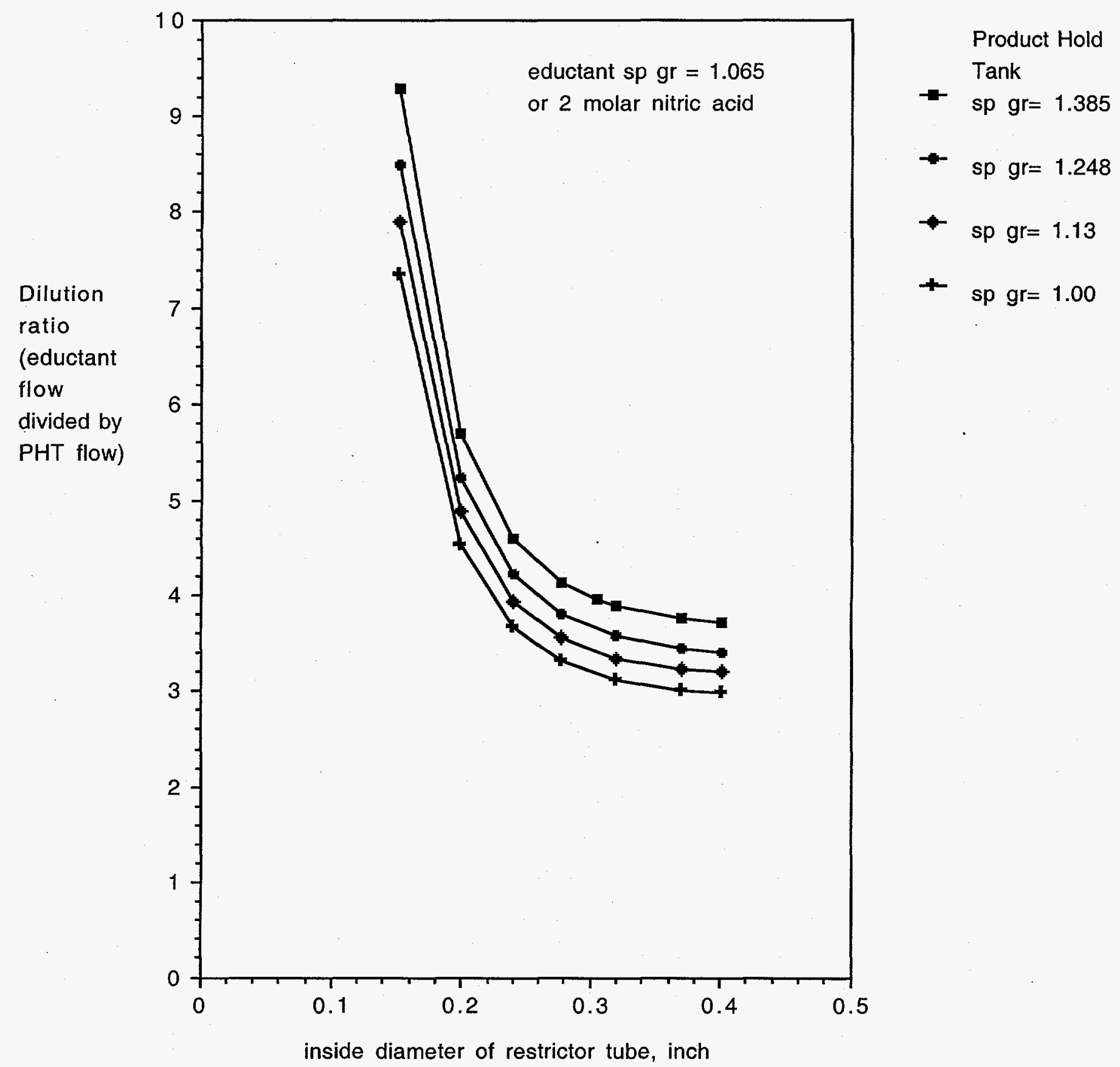

Figure 5

Calculated Dilution Ratios for Different PHT Specific

Gravities and Restrictor Diameters 
page 14

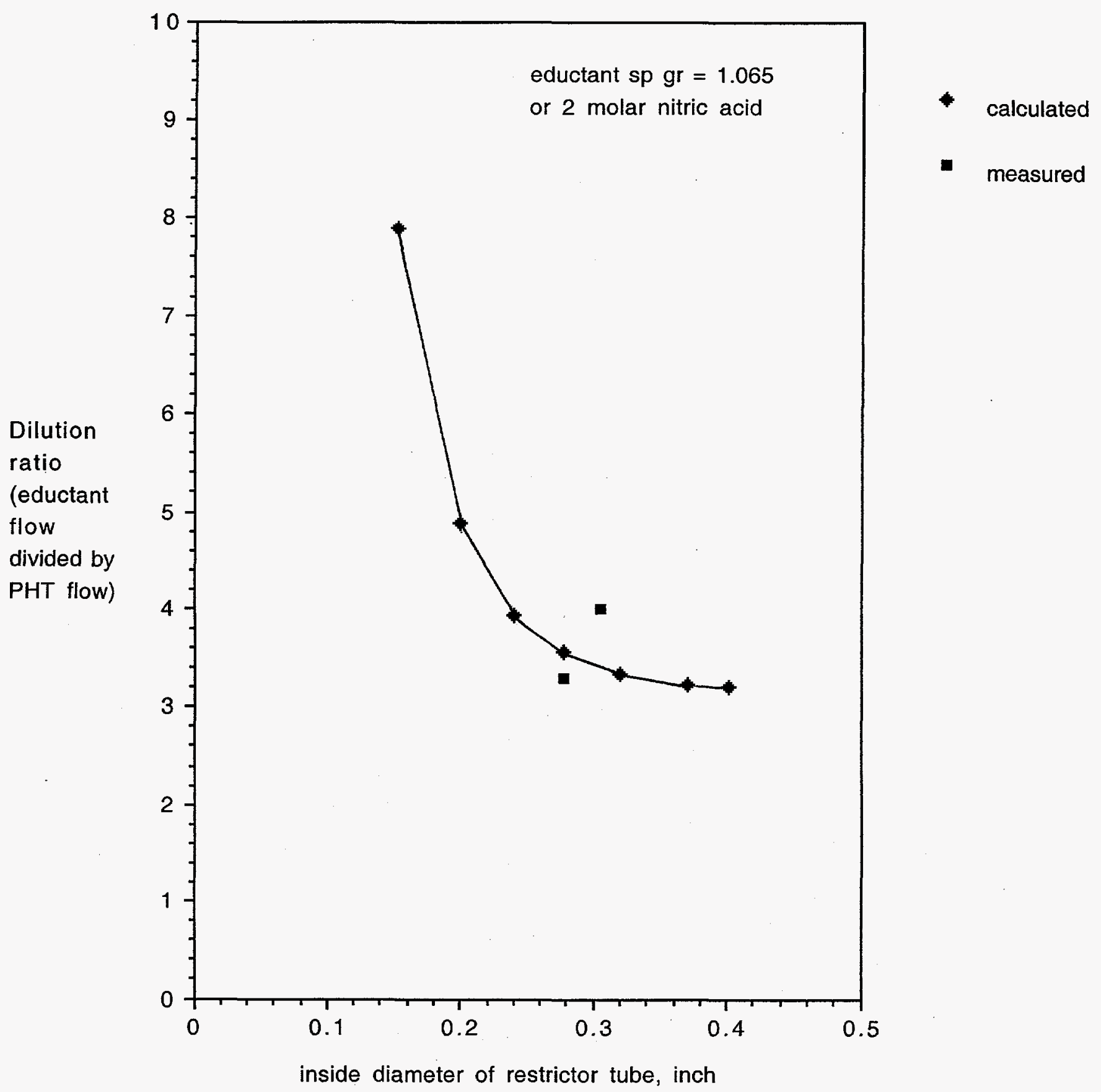

Figure 6

Calculated and Measured Flow Ratios for Product Hold

Tank Specific Gravity $=1.13 \quad(4 \mathrm{M})$ 


$$
\text { page } 15
$$

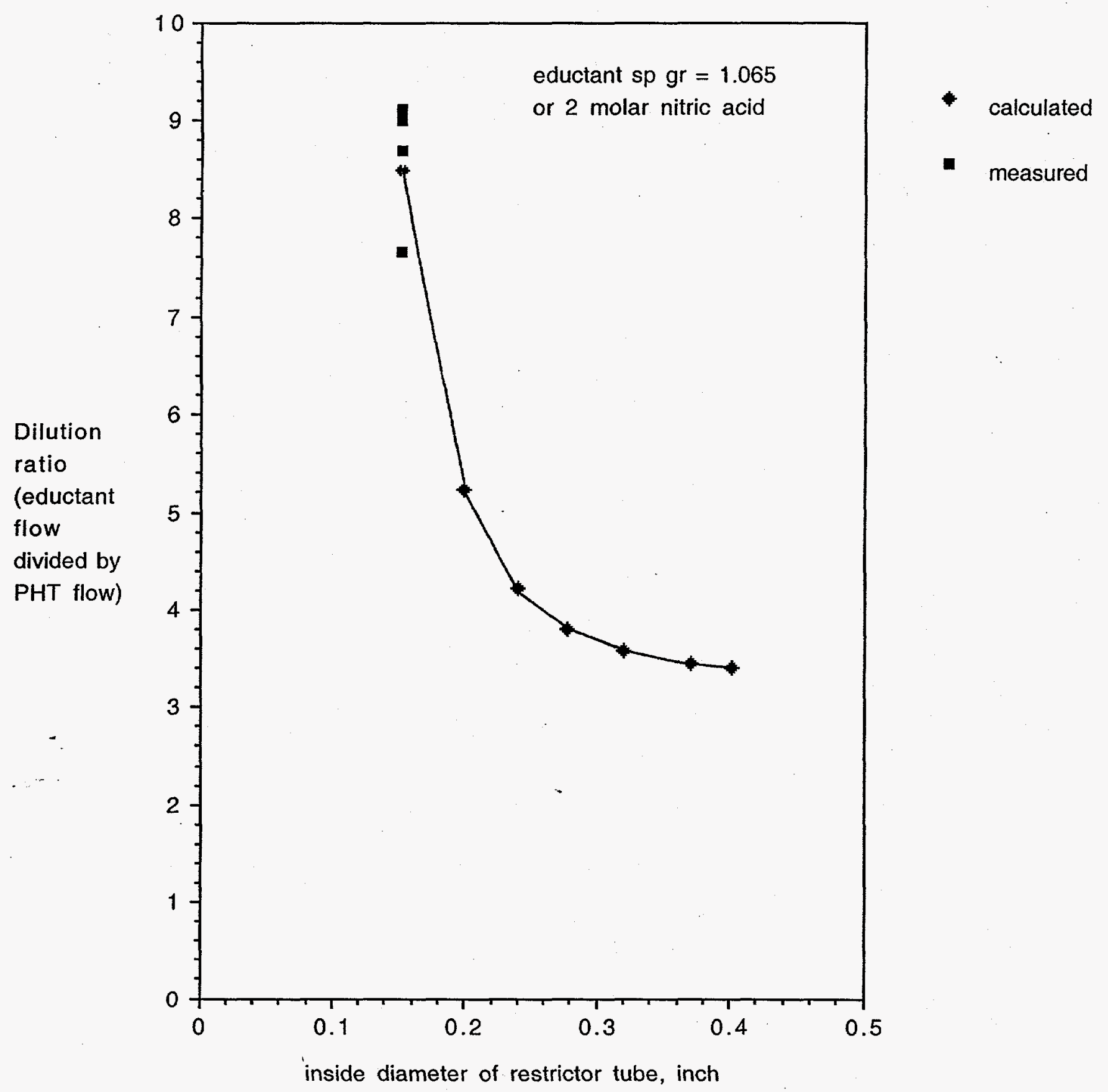

Figure 7

Calculated and Measured Flow Ratios for Product Hold Tank Specific Gravity $=1.248 \quad(8 \mathrm{M})$ 


$$
\text { page } 16
$$

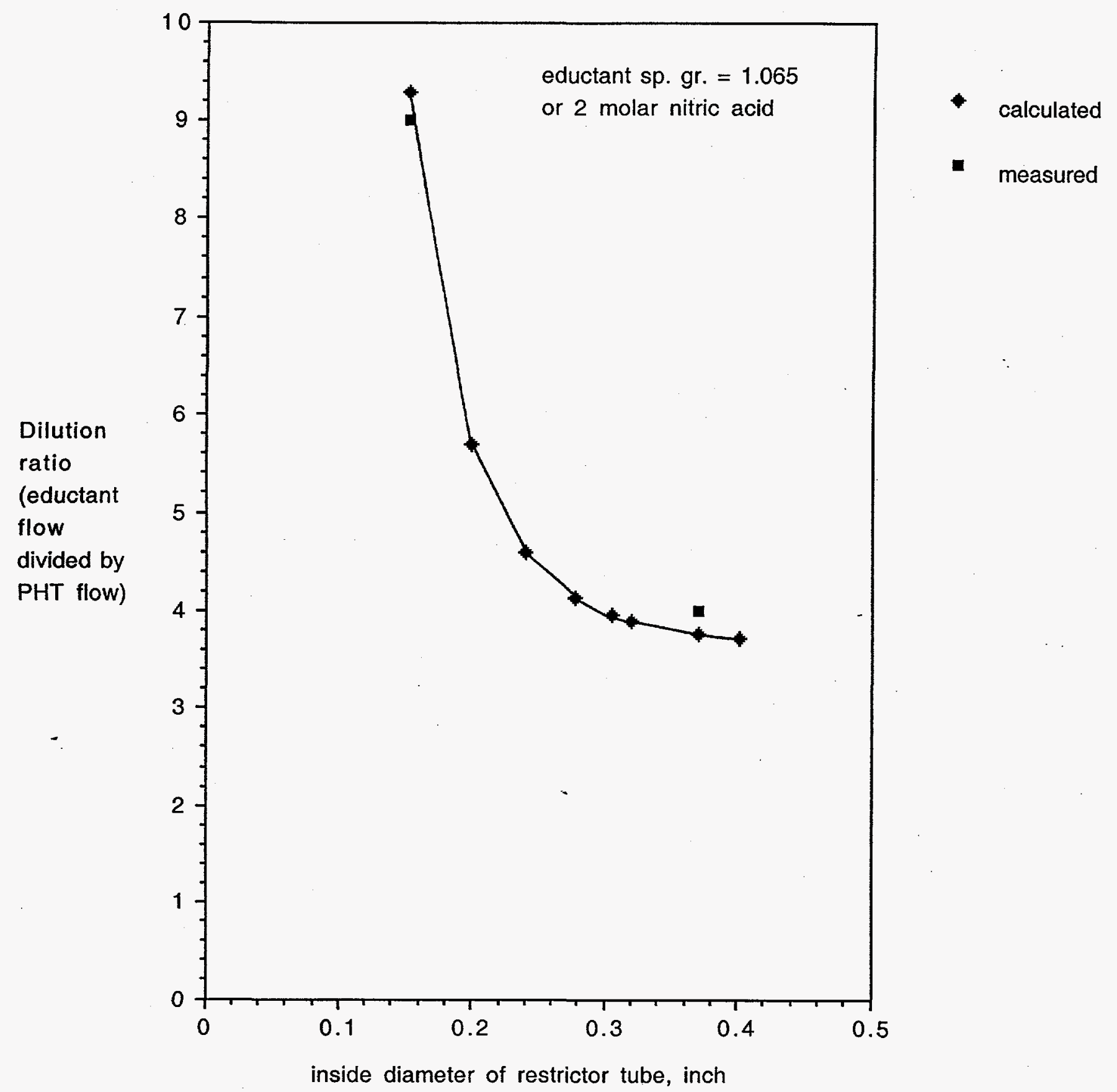

Figure 8

Calculated and Measured Dilution Ratios for Product Hold Tank Specific Gravity $=1.385 \quad(14 \mathrm{M})$ 


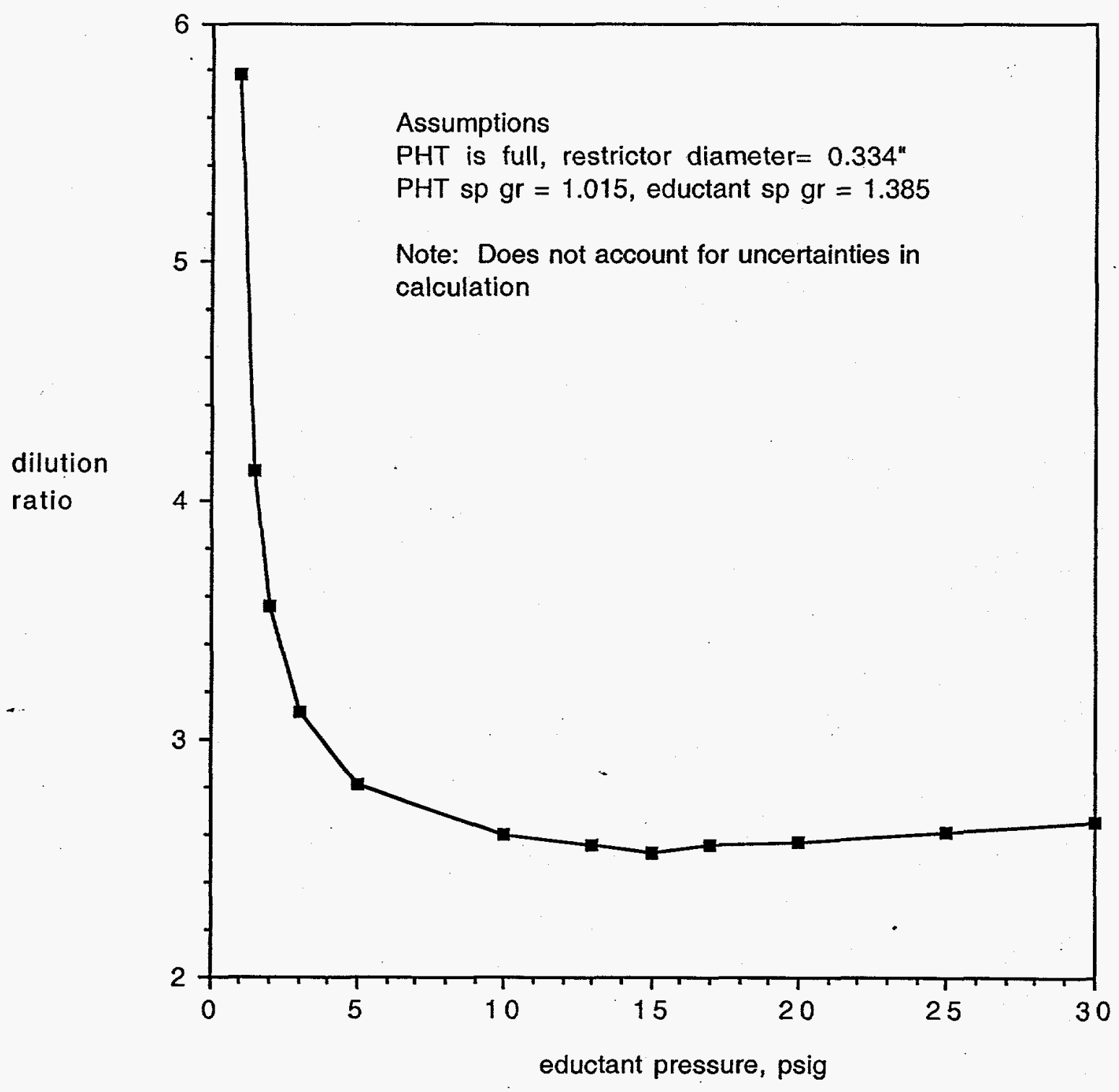

Figure 9 Dilution Ratio as Function of Eductant Header Pressure for Worst Case Conditions 